\title{
Land expropriation in tourism development: Residents' attitudinal change and its influencing mechanism
}

\begin{abstract}
The development of tourism projects is often predicated on land expropriation. It is therefore important to understand residents' attitudes towards land expropriation and how changes in those attitudes can benefit both the land expropriation process and tourism development. Taking Wudaoliang in Sandaogou village in Hebei province as a case study, this study focuses on residents' attitudinal change by taking a longitudinal approach involving nonparticipant observation and 180 interviews. Critical event analysis was conducted, and a framework for modelling attitudinal change was adopted. The results show that the attitudes of rural residents towards tourism development were not static but underwent a dynamic process of change across three phases. These results suggest that in such cases, residents should deepen their involvement in the land expropriation process and that information transparency can reduce social conflict, which will facilitate the sustainable development of rural tourism. The theoretical and practical contributions of this study are also discussed.
\end{abstract}

Keywords: Land expropriation; Longitudinal study; Attitude change model; Wudaoliang, China

\section{Introduction}

Many rural communities have embraced tourism because of its stimulus effects on economic growth (Gunce, 2003) and because tourism is an effective way to diversify their economies and reverse the outflow of their populations (Garrod, Wornell, \& Youell, 2006; Latkova \& Vogt, 2012). Research on destination tourism has increasingly considered local residents' perceptions of tourism development (Nunkoo \& Ramkissoon, 2011). There is growing consensus that the success of tourism development hinges on residents' attitudes towards the impact of tourism. These attitudes are becoming important considerations in tourism policy and planning, and they have implications for a destination's future success and sustainability (e.g., Ap, 1992; Lankford \& Howard, 1994; Nunkoo \& So, 2016; Ribeiro et al., 2017; Sharpley, 2014). Many studies have examined residents' attitudes towards later stages of tourism development in mature destinations, where tourism is already economically important (Belisle \& Hoy, 1980; Brougham \& Butler, 1981; Hernandez, Cohen, \& Garcia, 1996; Liu \& Var, 1986; Madrigal, 1993; Mason \& Cheyne, 2000). However, there has been limited research on residents' attitudes in developing regions in the pre-tourism stage prior to any development or recognition of tourism value (Ji, Jiang, \& Xie, 2017; Mason \& Cheyne, 2000; Sharply, 2014).

China provides an appropriate context for the study of residents' attitudes in the pretourism stage because it is a typical developing country undergoing a period of rapid economic and social transformation. At the beginning of 2018, China proposed the 'rural revitalisation' strategy to solve problems affecting farmers and agriculture and to revitalise the countryside. Due to its capacity to stimulate economic development, tourism has become particularly important for implementing this rural revitalisation strategy. In 2016, China's rural tourism investment was US $\$ 4.41$ billion, with more than 2 million rural tourism enterprises, 1.36 billion rural tourists and over US\$58.8 billion in rural tourism revenue (Chinese Academy of Social Sciences, 2017). Rural tourism development is a long-term process, and land expropriation is a necessary stage of tourism development. The gap between the demand for and supply of land for tourism development is widening nationwide, with the shortage of land restricting industrial development. Consequently, land expropriation has become one of the main solutions for securing land for tourism development (Ma, 2017). This paper focuses on the attitudes of 
residents towards land expropriation in the context of tourism development.

Rural residents in China have a traditional Confucian culture and a deeply rooted attachment to their land, considering it to have value as a source of income and as a marker of social status. Land expropriation is a process of land appreciation and income redistribution. The top-down structure of decision-making in China means that the government takes the leading position in the land expropriation process (Wang \& Wall, 2007). Therefore, tensions naturally arise between tourism developers and rural residents, who often go to great lengths to protect their land. Exploring Chinese rural residents' attitudes towards tourism development not only provides insight into residents' attitudes in general but also contributes to an understanding of the rural tourism and sustainable development processes.

Given the paucity of research and the importance of land expropriation for tourism development and social stability, this study sheds lights on the pre-tourism stage in the countryside of developing countries. The purpose of this study is to analyse residents' attitudinal changes in the context of land expropriation in Wudaoliang, China. Two questions emerge. What are residents' attitudes towards land expropriation when they lack a clear understanding of the possible consequences of tourism development? What are the mechanisms of attitudinal formation and change? This study addresses these questions in the stage just before the actual development of a tourism destination using a longitudinal approach.

\section{Literature Review}

\subsection{Residents' attitudes towards tourism development}

Residents' attitudes towards tourism development are critical predictors of their support for and participation in tourism development and of the achievability of sustainable tourism development and management (Gursoy et al., 2002; Nicholas et al., 2009). It is therefore not surprising that a great deal of academic attention has been paid to host communities' attitudes towards tourism development in general and towards the social, economic and environmental impacts of tourism in particular.

Tourism has a direct and significant impact on communities and their residents (Andereck et al., 2005; Sharply, 2014). Tourism can create employment opportunities and lead to more jobs (Dyer et al., 2007; Lankford \& Howard, 1994; Liu, Sheldon, \& Var, 1987), improve the local economy (Gursoy \& Rutherford, 2004), increase local income and living standards (Belisle \& Hoy, 1980), attract new businesses and improve investment (Andereck et al., 2005; Dyer et al., 2007), enhance recreational and entertainment opportunities (Dyer et al., 2007; Liu, Sheldon, \& Var, 1987), foster national cultural identity and pride (Andereck et al., 2005) and promote both the use and the protection of resources and the environment (Akis et al., 1996; Andereck et al., 2005).

As identified in the literature, tourism can also induce negative effects by increasing the cost of living (Akis, 1994; Liu \& Var, 1986; McGehee \& Andereck, 2004), raising the prices of goods, land and housing (Andereck et al., 2005; Belisle \& Hoy, 1980), creating shortages of goods (Belisle \& Hoy, 1980), increasing property taxes (Latkova \& Vogt, 2012), increasing traffic congestion (King et al., 1993; Ko \& Stewart, 2002; Latkova \& Vogt, 2012), aggravating crime rates and drug use (Andereck et al., 2005; Belisle \& Hoy, 1980; King et al., 1993; Ko \& Stewart, 2002), increasing the public consumption of alcohol (Ko \& Stewart, 2002; Latkova \& Vogt, 2012; Tosun, 2002), creating overcrowding and excessive demand for public services and facilities (Brunt \& Courtney, 1999; Lindberg \& Johnson, 1997), reducing residents' hospitality (Liu \& Var, 1986) and worsening environmental pollution (Ko \& Stewart, 2002; Yoon, Gursoy, \& Chen, 2001).

According to social exchange theory (SET) (Ap, 1992), the balance of residents' perceptions of the costs and benefits of tourism development is a major factor in tourist 
satisfaction, and it is therefore vital to the success of the tourism industry. If local communities perceive the costs of tourism to outweigh the benefits, they will withdraw their support for tourism, which will threaten the future success and development of the sector (Andriotis \& Vaughan, 2003; Lawson, Williams, Young, \& Cossens, 1998). However, most studies of residents' perceptions of the impact of tourism development are based on the later stage of tourism development. Little research has considered attitudes prior to the development of tourism in developing countries, especially at the initial stage, when the community's support and involvement are critical to success (Teye, Sönmez, \& Sirakaya, 2002). When tourism has not yet developed, residents have different attitudes towards and perceptions of it. It is therefore necessary to conduct research on residents' attitudes prior to tourism development (Sharply, 2014).

This paper focuses on the attitudes of residents towards land expropriation in the context of tourism development. It should be noted that in the process of China's rapid economic development, land expropriation may have different purposes, such as tourism development, dams, public works and investment projects. Residents may develop different attitudes towards land expropriation in different contexts. In general, residents may receive economic compensation regardless of the land expropriation purpose. It is notable that residents' attitudes towards tourism-related land expropriation differ from those towards land expropriation for non-tourism purposes, as residents believe that tourism development can create more employment opportunities for them and that they can participate in it. Thus, in economically less developed villages, residents generally hold welcoming attitudes towards land expropriation and look forward to participating in tourism development at the beginning even when their understanding of the project is limited (Akis, Peristianis, \& Warner, 1996; Doxey, 1975; Faulkner \& Russell, 1997; Hernandez, Cohen, \& Garcia, 1996; Upchurch \& Teivane, 2000).

\subsection{Factors influencing residents' attitudes}

Residents' positive and negative perceptions of tourism are influenced by various factors (Andereck et al., 2005; Ap, 1992; Gursoy et al., 2002; Ko \& Stewart, 2002; Latkova \& Vogt, 2012; McGehee \& Andereck, 2004; Nicholas et al., 2009). In the tourism context, SET (Ap, 1992) has been used as a theoretical basis for explaining host communities' perceptions and motivations (Gursoy et al., 2002; Ko \& Stewart, 2002; Latkova \& Vogt, 2012; Nunkoo \& Ramkissoon, 2012; Nunkoo, Smith, \& Ramkissoon, 2013). Most related research focused on how socioeconomic variables influence residents' perceptions, including age (McGehee \& Andereck, 2004; Tomljenovic \& Faulkner, 2000), living distance from tourist attractions (Hernandez, Cohen, \& Garcia, 1996; Weaver \& Lawton, 2001), length of residence (McCool \& Martin, 1994), level of knowledge about the industry (Andereck et al., 2005) and gender (Mason \& Cheyne, 2000). Several studies have examined the influence of community attachment on residents' attitudes (Latkova \& Vogt, 2012; McGehee \& Andereck, 2004; Tosun, 2002; Um \& Crompton, 1987; Sheldon \& Var, 1984).

Residents' perceptions of tourism impacts are also related to the level of economic activity of the community. Johnson, Snepenger and Akis (1994) used a longitudinal research design to investigate residents' perceptions of tourism development in a rural ski area experiencing an economic transition. Over six years, residents' attitudes changed from high expectations of tourism to diminished support. Allen et al. (1993) found that communities with low tourism development and low total economic activity viewed tourism development more favourably than communities with low tourism and high economic activity. Residents living in rural areas might perceive tourism as an important economic development strategy (Latkova \& Vogt, 2012).

As a number of studies have shown, residents' attitudes towards tourism are complex, as 
they are influenced by multiple factors. Residents are not a homogeneous group, and their reactions to tourism vary (Ap \& Crompton, 1993; Brougham \& Butler, 1981; Davis, Allen, \& Cosenza, 1988). Individuals may be ambivalent towards tourism (Hernandez, Cohen, \& Garcia, 1996). SET helps explain this ambivalence. According to Ap (1992), residents evaluate tourism in terms of expected benefits and costs. However, because they have no prior experience of similar types of resorts, they may feel ambivalent because of the high level of uncertainty associated with the expected costs and benefits. Residents in more mature tourism destinations will be more aware of the positive and negative impacts of tourism (Liu, Sheldon, \& Var, 1987) and more certain of what to expect (Hernandez, Cohen, \& Garcia, 1996).

However, much of the relevant research is restricted to case studies in the developed world, such as North America, Australia, New Zealand and the UK (Nunkoo \& Gursoy, 2012), Italy and Cyprus (Akis, Peristianis, \& Warner, 1996). The developing world has also been largely overlooked, although studies have been conducted on Fiji (King, Pizam, \& Milman, 1993), Ghana (Teye, Sönmez, \& Sirakaya, 2002), Uganda (Lepp, 2007), Iran (Zamani-Farahani \& Musa, 2012), and Mauritius (Nunkoo \& Gursoy, 2012). China is a typical developing country experiencing rapid tourism development. Therefore, the implications generated from the current study can be considered by other countries/regions facing similar issues.

\subsection{Level of tourism development}

In addition to micro-level factors, the macro-level stages that characterise tourism development affect residents' attitudes (Yoon, Gursoy, \& Chen, 2001). In other words, residents' attitudinal changes correspond to the sequential stages of tourism development (Allen, 1993; Butler, 1980; Doxey, 1975; Johnson et al., 1994). Many tourism scholars have used stage-based models to describe destination development and residents' reactions to tourism (Ap \& Crompton, 1993; Butler, 1980; Doxey, 1975). Butler (1980) proposed the concept of the tourism area life cycle, which has since been widely used to describe tourism development and residents' attitudes. This model shows that as the number of tourists at a destination increases, the residents who had once been overwhelmingly well-disposed towards tourists tend to develop growing reservations about the long-term benefits of tourism. Doxey (1975) used the earlier Irridex model and showed that residents pass through sequential stages as the number of tourists increases, with initial enthusiasm being followed by apathy, irritation or even antagonism. In short, the models of Doxey's (1975) and Butler's (1980) suggest a change in residents' attitudes and their involvement in tourism over time (Mason \& Cheyne, 2000). Such research has suggested that residents' attitudinal change is staged-based, heterogeneous and dynamic (Ap \& Crompton, 1993; Brougham \& Butler, 1981; Davis, Allen, \& Cosenza, 1988; Huh \& Vogt, 2007; Yang, Ryan, \& Zhang, 2013).

However, Doxey's Irridex model has been criticised as implying a homogeneity of attitudes that in practice might not exist (Ryan \& Montgomery, 1994). Residents are not a homogeneous group, and their reactions to tourism vary (Ap \& Crompton, 1993; Brougham \& Butler, 1981; Davis, Allen \& Cosenza, 1988). Authors such as Hernandez, Cohen and Garcia (1996) and Lepp (2004) warned against assuming the validity of the Irridex model in all situations. Sofield (2003) argued that the process of moving from euphoria to antagonism is not linear, and he defined that process as one of 'adaptancy'. He relabelled Doxey's 'stages' as 'states of affairs' and argued that a community could move from one state to the next, return to an earlier state or even skip a state. Community responses to tourism development should therefore be viewed as a complex evolutionary process rather than as a linear series of changes (Horn \& Simmons, 2002).

Many studies have been conducted on residents' attitudes in the later stages of tourism development, when tourism has already become economically important (Belisle \& Hoy, 1980; Brougham \& Butler, 1981; Johnson, Snepenger, \& Akis, 1994; Liu, Sheldon, \& Var, 1987; Liu 
\& Var, 1986; Madrigal, 1993; Mason \& Cheyne, 2000). However, there are fewer studies on the perceived impacts before development or before tourism is seen as economically significant (Mason \& Cheyne, 2000; Sharply, 2014). Studies focusing on the pre-development stage can thus make valuable contributions to this area (Hernandez, Cohen, \& Garcia, 1996; Pizam \& Poleka, 1985).

Based on the observations above, it can be stated that in the pre-tourism stage, residents have little or no exposure to tourism. As Brougham and Butler noted (1981, p. 570):

An ideal investigation of the social, cultural, and economic effects of the tourist industry would need to look at a destination area both before and after the appearance of visitors and their associated phenomena. Such studies have so far constituted something of a rarity in the literature, because it is generally impossible to predict the growth of tourism with sufficient accuracy for appropriate areas to be demarcated for investigation.

Some researchers have examined residents' attitudes in the pre-development stages on this basis. Keogh (1990) conducted a survey in New Brunswick when tourism was in the proposal stage. He found that most residents were not well informed about tourism development. Hernandez, Cohen and Garcia (1996) researched a period just prior to tourism development, surveying residents' attitudes towards a proposed 'instant' enclave resort in Puerto Rico. They found that residents had mixed feelings, recognising both the costs and benefits of tourism. In accordance with Hernandez et al. (1996), Hunt and Stronza (2014) proposed the incorporation of additional stages at the front end. In describing the stage in which tourism has yet to occur, Butler (1980) observed an 'absence of tourism' in Nicaragua. Mason and Cheyne (2000) tested hosts' attitudes in a rural region of New Zealand towards a proposed tourism venture prior to its development.

Research has found that residents are largely ambivalent in the pre-development stage. Future research should examine attitudes towards tourism in terms of degrees of ambivalence, and the various components of respondents' attitudes towards tourism should be weighted by importance to better understand how overall attitudes are shaped. More research on residents' attitudinal change in the pre-development stage is necessary (Hernandez, Cohen, \& Garcia, 1996; Hunt \& Stronza, 2014; Mason \& Cheyne, 2000), and a longitudinal approach would potentially offer greater insight (Hernandez, Cohen, \& Garcia, 1996). Therefore, to compensate for the earlier research emphasis on the stages prior to tourism development, this study takes China, a typical developing country, and analyses residents' attitudinal changes longitudinally regarding land expropriation for tourism development.

\subsection{China's land expropriation system}

China features socialist public ownership of land. States own all urban land, and the village collective owns all rural land subject to restrictions on land use and transfer. The state may, in the public interest, expropriate and give compensation for land in accordance with the China Land Administration Law (CLAL). In this assignment of property rights, land development proceeds in two steps: land expropriation by the government from villages and land transaction between the government and potential land developers (Guo, 2001). Expropriated land is compensated by the developer who eventually purchases the land user right, not the government. As stipulated by law, compensation fees are paid for the loss of crops and to assist the village collective in relocating the agricultural population affected by land expropriation. China's Constitution clearly stipulates that the government is the only legal subject with the power of land expropriation. Local governments use land reserves to expropriate land from rural residents and transfer it to developers as construction land.

Chinese law forbids land expropriation without the consent of the owner. However, such consent is not always easy to obtain, as the dual urban-rural land and top-down decisionmaking system have existed for a long time, and many farmers are reluctant to give up their 
land due to their feelings for the land and love of rural life (Cao \& Zhang, 2018; Wang \& Wall, 2007). The property rights arrangement in rural China is unique in that land cultivated by individual households is owned by village collectives. Collective land ownership features what Ho (2001) called 'deliberate institutional ambiguity' - the term 'collective' is intentionally vague in the CLAL to solidify state control over rural land. Moreover, the CLAL gives the state the right to expropriate rural land for 'public use', the scope of which is also poorly defined. By design, this institutional ambiguity leaves significant room for the abuse of power by governments at various levels to expropriate rural land and convert it to non-agricultural uses, such as industrial and infrastructure projects and lucrative real-estate development. Moreover, the government typically compensates land-losing farmers according to their land original use and then auctions off the expropriated land based on its future value. The government thus obtains massive profits (Cai \& Sun, 2018; Shang, 1998).

In contrast with that in China, developed countries' land expropriation has clear and fair land use scope and adjustment mechanisms (Cai \& Sun, 2018). For example, developers must follow clear rules, and land expropriation must be for the public interest and in line with the specified scope. In addition, in the West, the government, developers and residents discuss compensation together. In contrast, residents are largely excluded from this process in China.

In addition to tourism development, other purposes of land expropriation in China include the development of dams, public works and investment projects. However, land expropriation for tourism development is quite different from that for public works and general investment projects. In the pre-tourism development stage, residents have not yet had any direct experience of tourism in their community, but they have positive expectations (Hernandez, Cohen, \& Garcia, 1996) because they expect employment opportunities and other forms of resident participation in tourism development after land expropriation.

However, land expropriation, which is central to the government's development and capital accumulation strategies, has frequently encountered fierce opposition from farmers and caused sharp social conflicts (Mathur, 2013; Sargeson, 2016). Land expropriation in China has aroused widespread concern in both academic and practical circles. One of the challenges is that the land compensation price established under the planned economic system is much less than the land value in the market economy (Guo \& Gao, 2014). Land is the most important asset of the majority of rural residents because it functions both as a source of income and as a mechanism of social insurance (Cai, 2016). Thus, the land expropriation process plays an important role in rural residents' well-being and overall quality of life. It is therefore urgently necessary to explore the land expropriation issues in tourism development, particularly in rural areas in developing countries.

\section{Theoretical framework}

The persuasion situation model initially proposed by Hovland (Hovland \& Weiss, 1953; Sherif \& Hovland, 1961) and refined by Freedman (1985) was adopted as the theoretical framework for the current study. This model includes four essential stages for interpreting the entire attitudinal change process: external stimuli, targets, intervening processes and outcomes. It starts with the external stimuli, which cover the communicator, communication and situation. Second, all of the external stimuli act on the target, whose individual characteristics may greatly influence the persuasion effect. For instance, individuals' prior commitment, inoculation and personality may influence their attitude changes. The third stage is intervening processes, where the communicators try to persuade the targets via message learning, transfer of affect, consistency mechanisms and counter-arguing. In the fourth stage, the outcomes of persuasion can be attitude change or source derogation, message distortion and blanket rejection. This framework has been widely cited in and adopted by research in various disciplines, such as consumer research (Friestad \& Wright, 1994; Petty, 2018; Khantimirov \& Karande, 2018), 
communication (Petty \& Cacioppo, 1986) and social psychology (Jones et al., 1968; Clementi, Revelli, \& Sibona, 2015).

The objective of this study is to explore the attitudes and mechanisms of Wudaoliang residents in the early stage of the tourism life cycle, specifically those relating to tourist development and the land expropriation process. The analytical approach of the persuasion situation model, with its association between persuasion and attitudinal change, gives it strong applicability. Moreover, the model covers both internal and external factors that influence an individual's attitude change; thus, this analysis path has strong explanatory power for the current study. Land expropriation for tourism development is a long-term multi-subject competition between interests, and residents' attitudinal changes depend on the external stimuli. However, residents' attitude formation is rooted in individuals' characteristics and empirical judgements, which emphasise internal stimuli. This framework thus provides a deeper understanding of residents' attitudinal changes regarding land expropriation for tourism development.

\section{Methodology}

\subsection{Research context}

The study site of Wudaoliang is located in Sandaogou village, Laowa township, Luanping county, Chengde city, Hebei province. By the end of 2016, the village had 77 households and 228 people. Deep in the Yanshan Mountains and at a high altitude, Wudaoliang has poor road conditions, making transportation difficult. The living conditions are also quite poor. Due to the area's rich potential for tourism, with resources such as the Ming Dynasty Great Wall and ancient fossils, the Luanping county government and a Beijing investment company signed the Anaya Jinshanling Project Cooperation Agreement on 11 April 2016. Under this agreement, the Beijing company was to develop the overall tourism infrastructure of Wudaoliang, and the government was to initiate the project by expropriating 110 acres of agricultural land, which was productive land that was important for the residents' long-term survival. After the land expropriation agreement was signed, all affected households were notified of the housing demolition resettlement details by the government at a later stage.

Facing the loss of both their land and their peaceful lifestyle, the residents of Wudaoliang felt tremendous strain. This psychological state of 'being swayed by considerations of gain and loss' largely defines rural residents' experience of land expropriation for tourism development in China. Conclusions drawn from this case can provide useful guidelines for land expropriation policy making to better address the interests of all concerned parties.

\subsection{Research design, data collection and analysis}

Qualitative methods can provide a better understanding of the phenomena under consideration than more traditional quantitative methods (Hernandez, Cohen, \& Garcia, 1996). Most of the research in this area has used quantitative methods to cluster residents' perceptions and attitudes, but such methods cannot explain the mechanisms and motivations behind those perceptions and attitudes (Sharpley, 2014). This research explores residents' attitudinal changes and their driving mechanism in the context of land expropriation in the pre-tourism stage in Wudaoliang, and qualitative methods are well suited to this purpose. Wudaoliang's permanent residents can be characterised by certain attributes. Most young residents have left the area for work. The elderly and children constitute the main body of permanent residents, but together, they account for less than one third of the registered population. An overly detailed scale or questionnaire is not helpful for identifying the real attitudes of these residents towards land expropriation; non-participant observation and unstructured in-depth interviews (Churchill, 1991; Smith, 2010) can more effectively identify residents' attitudes. 
The focus of this research is residents' attitudinal changes in the context of land expropriation. This change is a process that requires longitudinal research, which, despite being rare in tourism, can offer rich insight into how experiences develop and evolve over a multiday stay (Ingram, Caruana, \& McCabe, 2017). Several studies have examined residents' attitudes via a longitudinal approach. Johnson, Snepenger and Akis (1994) used a longitudinal research design to investigate residents' perceptions of tourism development in a rural ski area undergoing economic transition. Over six years, the residents' attitudes changed from initially high expectations to diminished support. Yang, Ryan and Zhang (2013), in a study based on 12 months of ethnographic study, used social conflict theory to suggest a four-part model to describe how tourism engenders different forms of social conflict and produces fluctuating alliances between stakeholders in China. Hernandez, Cohen and Garcia (1996) used a longitudinal approach to examine residents' attitudes towards the proposed 'instant' enclave resort of Isabela, Puerto Rico. Longitudinal data may offer greater insight into residents' attitudes towards tourism development (Johnson et al., 1994). Researchers have also emphasised the value of the longitudinal approach in investigating residents' attitudinal changes across the development phases of a tourist site (Carmichael et al., 1996; Getz, 1994; Lee \& Back, 2003). A longitudinal approach was also used to investigate the attitudes of residents facing land expropriation in the pre-tourism stage in Wudaoliang.

Non-participant observation revealed two key events in the land expropriation timeline that concerned Wudaoliang residents and had significant impacts on their attitudes. First, there were two related announcements on 16 May 2016: 'Luanping county people's government's announcement on the land planning of Wudaoliang land in Sandaogou village' and 'Luanping county people's government's announcement on the land expropriation of Wudaoliang in Sandaogou village'. These announcements signified that an agreement had been reached between the government and developers. The development of tourism in Wudaoliang, which had once been uncertain, became fact. The second key event was the village committee's announcement on 26 July 2017 that "with the approval of the township and through consultation by representatives of the two village committees and groups, the land expropriation agreement will be signed from 8:30 a.m. on 26 July 2017 to 4:00 p.m. on 2 August 2017'. The signing of the agreement suggested that upon receiving their compensation, the residents would completely lose their rights to use the land. Based on these two key events, the land expropriation process in Wudaoliang can be divided into three stages: 1) before the announcement; 2) after the announcement and before the signing of the agreement; and 3) after the signing of the agreement.

The main advantage of unstructured in-depth interviews (face-to-face interviews) over structured interviews is that they yield a better understanding of respondents' thinking (Churchill, 1991). In the in-depth interviews conducted for this study, the questions were openended and unstructured. Non-participant observations were also included.

Wudaoliang is the hometown of the first author, who has good relations with its residents and government officials and is familiar with its entire tourism development process. The first author regularly returned to his hometown on weekends and holidays during the project period to interview and communicate with residents and officials. From 2016 to 2018, the second author went to Wudaoliang three times to conduct field research and spent 88 days with local people. During those 88 days, the second author became deeply involved in the local people's daily activities and established good relationships with them. After obtaining the consent of the interviewees, the interviews were recorded. The interviews focused on the interviewees' perceptions of key events in the land expropriation process. They did not psychologically burden or place pressure on the interviewees, but guided them to describe their stories and express their emotions. Non-participant observation was also used to collect residents' attitudes. The government posts notices to inform the community at a large pine tree in the village, and 
this is where residents gather for discussion after dinner. In addition, the government held meetings in the village government building to make land expropriation announcements. Therefore, in the three stages, the author collected the attitudes and responses of the residents towards land expropriation through careful observation under the big pine tree and the place where the government held meetings for residents.

Overall, 180 interviews generated 536 pieces of original information. The key events of non-participant observation divided the residents' attitudes into three stages. The interview materials were then classified according to the three stages. The first stage (before the announcement) included 107 pieces of information from 39 respondents. The second stage (after the announcement and before the signing of the agreement) included 268 pieces of information from 39 respondents. The third stage (after the signing of the agreement) included 161 pieces of information from 39 respondents. The 39 respondents included 3 township government workers, 1 village party secretary, 1 village director, 25 ordinary residents, 7 residents who worked in other cities and 2 non-residents who lived in other cities but owned real estate in the village. The respondents ranged from 17 to 76 years old. This study also collected secondary data, including statistical data and statements related to social and economic aspects and to the development of tourism in Wudaoliang, and government documents and meeting minutes that supported the interview data and were used to sort the storylines.

The raw data underwent thematic analysis, which is a systematic technique for identifying, analysing and construing patterns of data, classifying them into themes (Clarke \& Braun, 2017). These themes include six stages: familiarisation with the data, data generation and initial codes, searching for themes, reviewing themes, defining and naming themes and interpreting the meaning of the themes (Creswell, 2014). The non-participant observations supported the interpretations of the major themes derived from the interviews. Quotes in the findings were labelled with the resident number, gender, age and interview time (year and month).

\section{Findings}

\subsection{Before the announcement}

Before the land expropriation announcement, news about tourism development had spread among the residents of Wudaoliang. With the continuous field visits by the developers and the establishment of nearby tourism projects such as the Jinshanling international shooting range, speculation over tourism development in Wudaoliang had become a popular conversation topic. Eager to surmount the challenges posed by geography, the difficulty of accessing potable water, inconvenient transportation and the psychological toll of pursuing a better life, the residents had high expectations for tourism development.

Hurry and develop! When it rains, the road is mud, and there is no way to go. In this case, you must go to the only well in the village to get water, or you have no water to drink. My daughter has already been married in Beijing. We will go to Beijing to stay with our daughter sooner or later. Today, our own physical condition is not too bad. If the village can develop, we can help our daughters after receiving our compensation so that we don't become a burden. (Participant 5, Female, 67, 201601)

To reap the benefits of development, a few 'far-sighted' residents planted higher-value cash crops. Subsequently, more residents began to think strategically and promote tourism development.

In the case of tourism development, the seedlings I planted are worth the money. The compensation standard for corn is too low. According to our compensation regulations [China's property law and land management law stipulate that different types of crops have different levels of compensation], the compensation standard for saplings is higher. The 
seedlings I bought cost only a little more than US\$3 when they were $3 \mathrm{~cm}$ in diameter. Once tourism is developed, the developer will give me US\$1,176. (Participant 18, Male, 50, 201603)

However, when the news of tourism development failed to translate into reality, the reality that no movement had yet been made set in. Meeting to discuss whether and when tourism development might actually be carried out became some of the residents' favourite activities.

Why wasn't there any news about tourism development? What happened? Are they not coming to invest in development? How can the government be so useless? (Participant 26, Male, 52, 201603)

As official and unofficial information was scant, the residents' attitudes during this period were defined by the desire to obtain more accurate information. The residents were often dissatisfied with words and deeds that were not conducive to development, and any negative news affected their mood.

A while ago, there were companies conducting field investigations, so how is it that these companies only travel here and have no follow-up news? (Participant 37, Female, 53, 201603)

As shown in Figure 1, before the land expropriation announcement, residents from the same village, residents from the other villages, friends and relatives acted as communicators. Wudaolaing residents were focused on tourism development news. With inconvenient living conditions and limited information access, the residents planned to serve their individual interests in a variety of ways. They were generally open to land expropriation and tourism development and expected that this project would improve the welfare of the village. At this stage, because of the positive expectation that tourism development would make life better, Wudaoliang's residents formed anticipatory and collectively supportive attitudes towards land expropriation for tourism development (Figure 1).

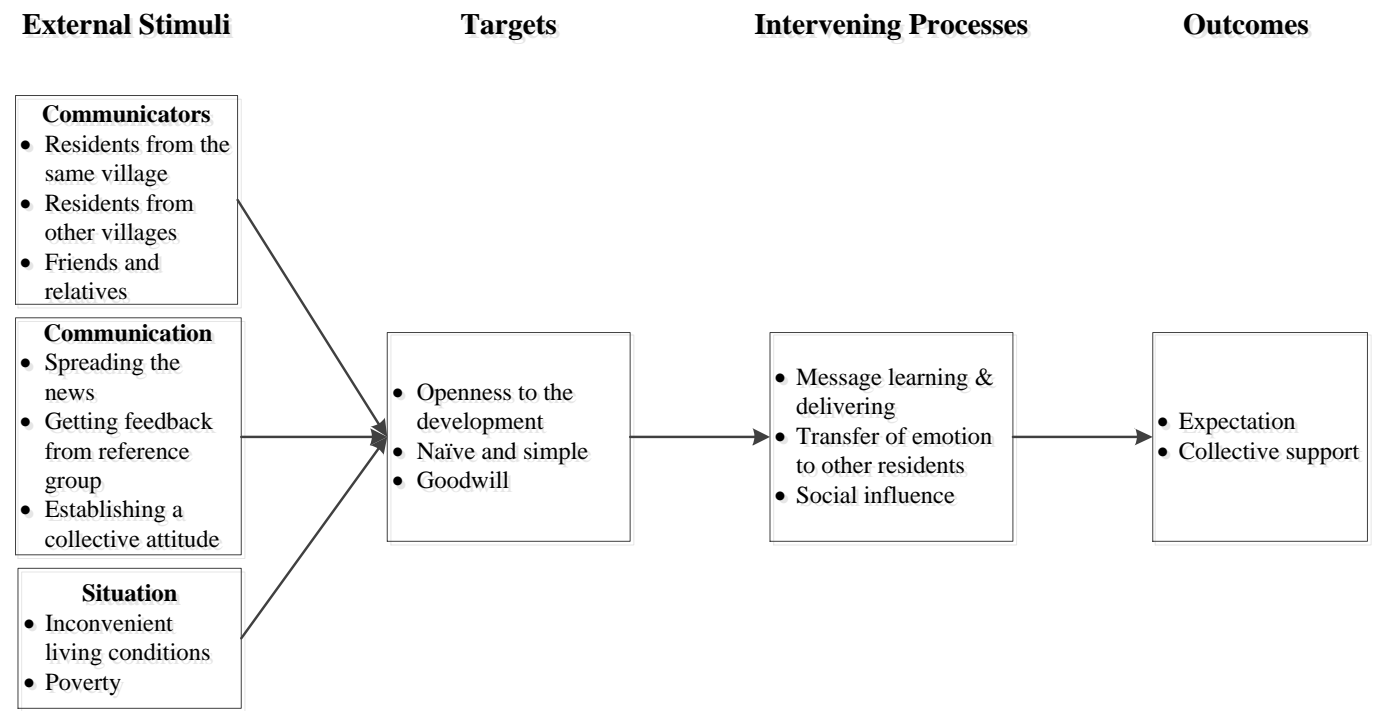

Figure 1. Process of residents' attitudinal changes before the announcement

5.2. After the announcement and before the signing of the agreement

Two official announcements were made on 16 May 2016, one relating to land planning and the other relating to land expropriation. Upon receiving this news, the residents began to form new ideas that included negotiating compensation terms with developers and never to stimulate the government to implement drastic measures.

We almost got it. Don't go too far. Otherwise, the developers will be scared away by everyone's conditions regarding land expropriation. If we negotiate with the government, I am afraid it will have the power to arrest troublesome residents. (Participant 9, Female, 46, 201605)

In this phase, the residents were focused on compensation for land expropriation and 
housing demolition. The objects involved in this dispute included the scope of land expropriation, time of land expropriation, price of land expropriation, compensation for objects attached to the land, land measurement and identification, payment of social endowment insurance for land-losing farmers and time and progress of compensation payments.

Next, let's see how the government compensates us for land expropriation. The government of Hebei province has determined that the original land price of Luanping county Laowa township is US\$11,000 per acre. Based on the actual situation in this region, the compensation price in Wudaoliang village is US\$11,765 per acre, and the compensation price of unused land is US\$7,059 per acre. So how does the government set these compensatory standards? According to the laws and regulations, we have the right to participate in setting these standards, but we simply let the government do so in a process that we did not understand! I won't let them take over my land if the compensation is not appropriate. We've all lived here for our lifetimes. Why would the government want us to move right away? Do they have the right to do that? (Participant 16, Male, 42, 201612)

Reflecting different interests and situations, people's appeals began to vary. For permanent residents living in poor conditions who owned no property, economic compensation and the improvement of living conditions influenced their attitudes.

I don't want to go so far to get water. Our living conditions will be improved after the development of tourism. (Participant 11, Female, 67, 201706)

For the elderly, emotional attachment to 'home' shaped their attitudes.

The environment in Wudaoliang is really good. There are no mosquitoes in the summer. The place is cool and the air is good. The only regret is that there is no convenient source of water. With water, no one is willing to leave their ancestral home. Our ancestors have lived here for generations. (Participant 29, Female, 76, 201706)

Some residents who did not have clear attitudes before were affected by the surrounding population and demanded higher economic compensation based on their own conditions and comparative advantages.

Government persuasion won't work either. Other people's homes were compensated at US\$147,059, and my home at only US\$29,411. Ask the government to compensate me for the saplings they removed from my land and I will agree to sign the agreement. [One night after the announcement, to get more compensation, the resident secretly planted more than 3,000 trees on his own land, which were discovered and pulled out by the working group.] The government needs to compensate me US\$29,411; otherwise I will not sign the agreement. (Participant 34, Female, 48, 201706)

The government is the executor of land expropriation in China. To facilitate the program's smooth implementation, the government publicly issued restrictions: 'Construction and expansion in the area designated for tourism planning is prohibited, as is rushing to build permanent or temporary structures. Areas designated for development must retain their attachments and fixtures according to the original layout'. To implement land expropriation, the government drew on its strength of economic and administrative mobilisation. For the residents of Wudaoliang, who were deterred from escalating their resistance by various messages to conform, the continuous increase of information resulted in their moving away from participating in larger gatherings and entering into small-scale discussions with family relations, which influenced the residents' collective decision-making attitude and behaviour.

Before the signing of the land expropriation agreement, the government became a main communicator, releasing two official announcements, disclosing more information about land expropriation and influencing surrounding people's words and deeds. The government had the power to mobilise and, possibly, to intimidate. This was a main external stimulus. Under the direct effects of these factors, the residents formed various appeals and responses based on their own families' conditions and characteristics, such as a fear of governmental power, interest in 
economic compensation, basic demands for improved lives, emotional attachment to places of residence and the search for comparative advantage. Through different intervening processes induced by various external stimuli and individual factors, the residents' attitudes were classified as firm support, conditional support, contradictory attitudes and firm opposition (Figure 2).

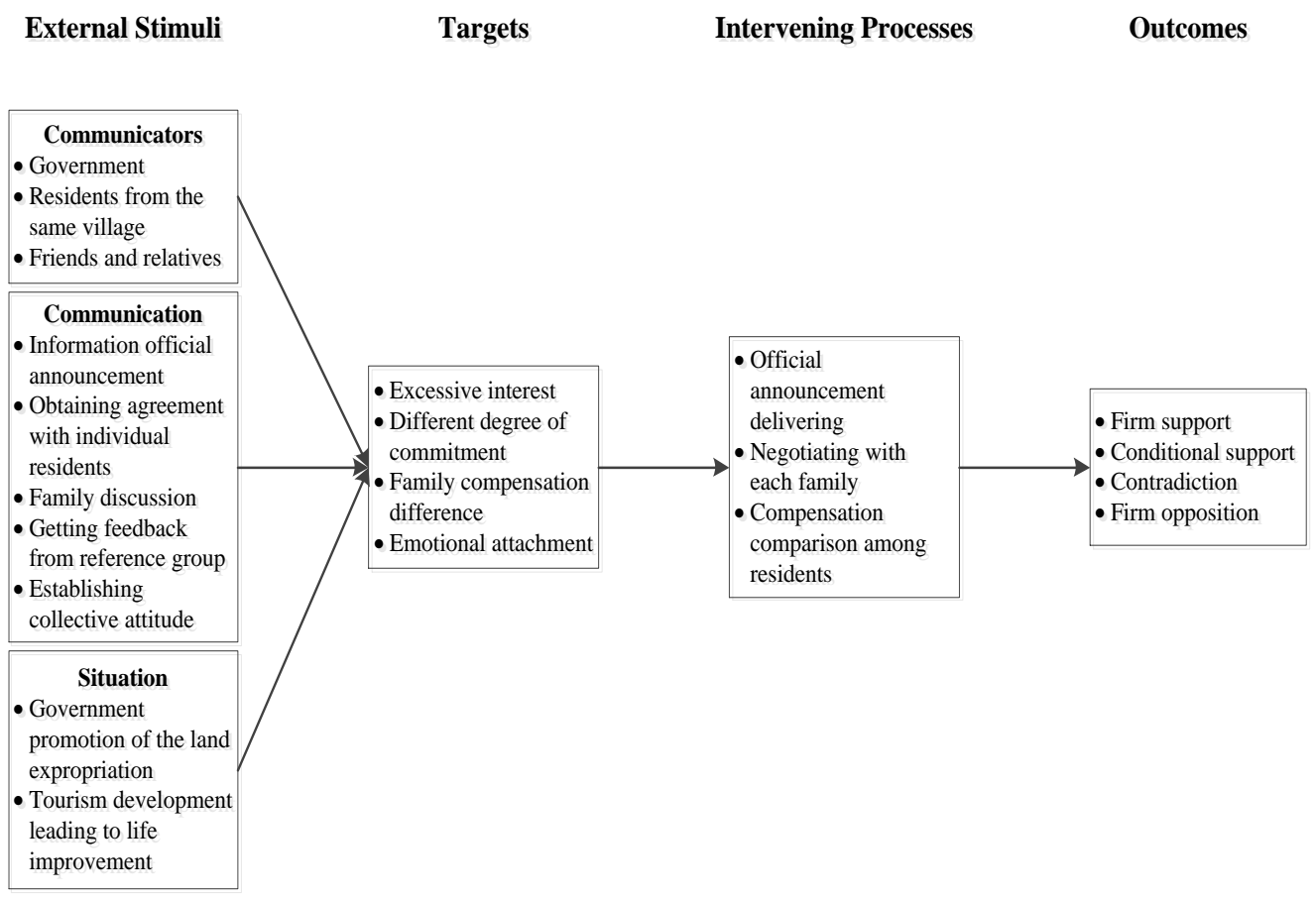

Figure 2. Process of residents' attitudinal changes after the announcement and before the signing of the agreement

5.3. After the signing of the agreement

From 26 July to 2 August 2017, 76 out of 77 households signed the land expropriation agreement with the Luanping County Land Reserve Center and received compensation for the first time. Unlike other land expropriation projects involving severe violence between stakeholders (Lin et al., 2018), the Land Expropriation Working Group encountered limited difficulties in Wudaoliang, and there were no cases of violence. After the signing of the land expropriation agreement, all of the agreeing households were notified of the housing demolition and resettlement details by the government.

This expropriated land is unique in that it is in the geometric centre of the village, surrounded by 154 acres of land that was not expropriated. Thus, a nested circle radiating outwards was formed to include residential houses, the expropriated land and unexpropriated land. Land scheduled to be expropriated is called 'nuclear land', and land that is not slated to be expropriated is called 'peripheral land'. In the case of Wudaoliang, land expropriation preceded the publication of housing value assessments and plans for demolition and resettlement, and there was a certain degree of non-synchronisation in their chronological order. The resettlement houses were not local, having been built in different places, and information about the surrounding or peripheral land was not disclosed in the land expropriation stage. Thus, most of the residents realised that if the government did not give appropriate compensation for the 154 acres of unexpropriated land on the periphery, then the free distribution of the peripheral land to the developer was to be expected.

The government and developer are apparently trying to bully us by claiming only the nuclear land. Also, the resettlement houses are not nearby. Who can commute so far from home 
to field? Is our peripheral land equivalent to giving away a business enterprise for nothing? Land compensation standards are low, and the government has all the advantages. (Participant 8, Male, 51, 201803)

The government's decision-making process for the location of the resettlement house was not transparent and we were not involved at all. All the decisions of the government were made without our participation. We had no choice but to accept it! (Participant 22, Male, 50, 201803)

Whether post-demolition resettlement was to be local and the manner by which peripheral land was to be disposed thus became bargaining issues for residents and developers.

Our resettlement house is not going to be placed in Wudaoliang? The government and developers are ganging up on residents. If the resettlement house is remote, no one will go there. I won't sign the agreement. Anyway, I am not going. (Participant 31, Male, 56, 201803)

It is better not to put the resettlement house in another place. Even a piece of land in Wudaoliang village will do. In the future, when tourism is developed, by not leaving Wudaoliang, we can open a farmhouse or at least work in the tourist area. If the resettlement house is far away, what will happen to our peripheral land? Who will come back to farm it? The government is only expropriating the nuclear land. It is actually illegal for us to give them peripheral land free of charge. (Participant 17, Female, 46, 201803)

There was no real agreement between the government and the residents. Only a few residents tried to defend their rights and resisted, citing land expropriation procedures, the insufficient participation of residents in decision-making and unsatisfied interests. The vast majority of residents were still forced to acquiesce under increasing persuasion and pressure, official or unofficial, knowing full well that their individual interests had been harmed.

The government uses various means to force residents to sign agreements. As long as the residents are of the same mind, there is still room for negotiation. We have a total of 77 households. As long as half of the residents do not agree, we will go through legal procedures to petition the government. They dare not do anything about us. We received the first land expropriation compensation, so the developer will not withdraw. The house is mine. We will not move back to Wudaoliang, following the resettlement requirements (Participant 22, Male, 50, 201803).

'Don't go too far', some resident said casually, and was arrested by the county public security bureau and confined for several days. (Participant 6, Female, 46, 201803)

After the land expropriation agreement was signed, additional information about the peripheral land and resettlement houses was released. Faced with losing their land and being forced to leave their 'homeland', more residents began to reflect on their true acquisition and loss in the tourism development process. To have a bargaining chip, the residents did not sign a house demolition agreement. Simultaneously, the government and developers began to use administrative and economic means to persuade and divide rural residents. Under the combined effects of these external factors, the residents gradually realised that their compensation benefits were low and their participation was minimal. In the face of this forced group marginalisation, the residents entered into limited competition with the external forces of the government and developers. Furthermore, the residents' responses, formulated under the stress of impending land expropriation, were counterproductive, and two distinct attitudes: resistance and compromise. Even knowing that their individual interests had been damaged, most of the residents were coerced into compromising by powerful interest groups. However, a few residents still strove to maintain their own interests and rights by calling upon legal design, procedural justice and social ethics, thus triggering a new round of action, reaction and attitude formation (Figure 3). 


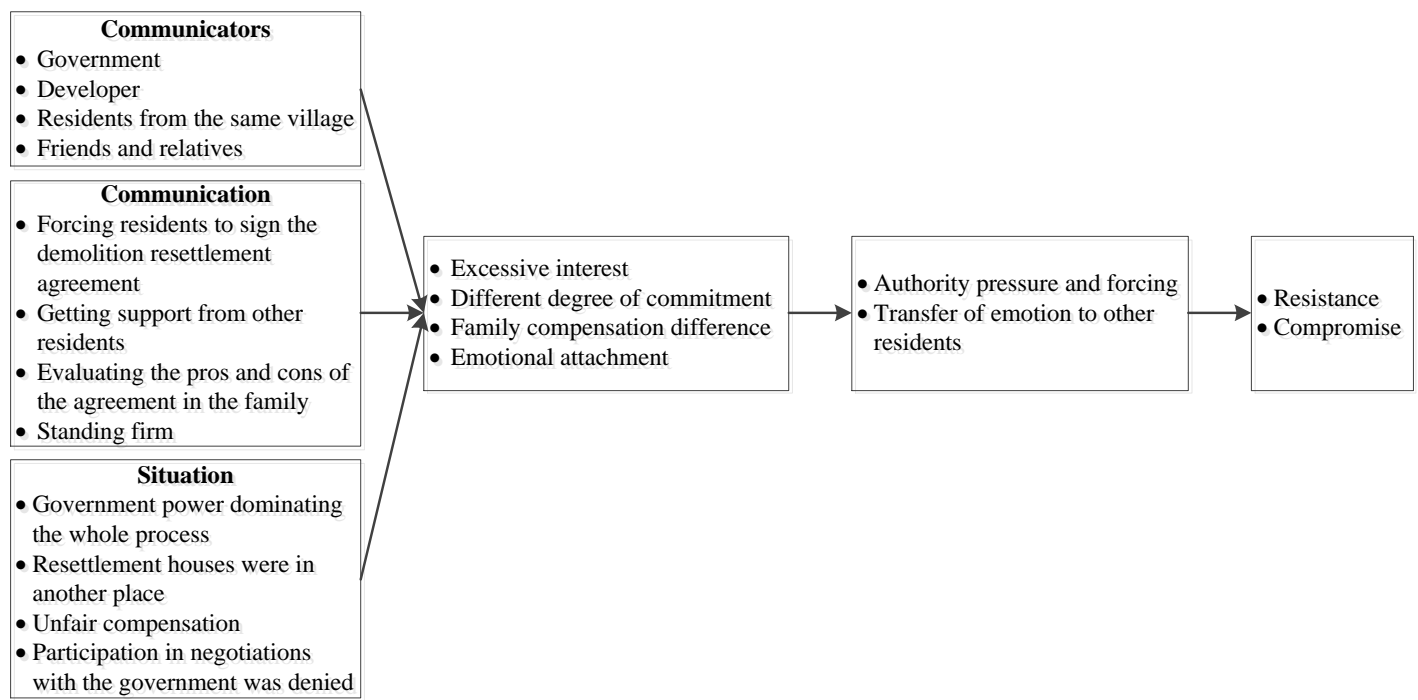

Figure 3. Process of residents' attitudinal changes after the signing of the agreement

\section{Residents' attitudinal change mechanism in the land expropriation stage}

Before the announcement, and in the absence of official explanations of the possible consequences of tourism development, the residents of Wudaoliang relied on rumours in making their decisions. They developed positive expectations of and collective support for land expropriation. After the announcement and before the signing of the agreement, detailed information, such as the scope of land acquisition and the price of land, were disclosed. This led to the residents attempting to maximise their interests and to individual differentiations in attitudes according to their own situations. After the signing of the land expropriation agreement, more information surfaced, such as the details surrounding resettlement and the lack of expropriation and compensation for peripheral land. The residents soon realised that they had been excluded from the tourism development process and that their actual interests had been greatly harmed. A new round of conflict of interests focused on housing and resettlement then began between the residents, the government and developers.

Information is a key factor in the changes in residents' attitudes. With the continuous disclosure of information in the land expropriation stage, including information about the formal announcement and agreement, the residents generated corresponding reactions, forming a three-stage attitudinal change process going from expectation and collective support to individual differentiation, resistance and compromise. Figure 4 depicts the residents' attitudinal changes across the information disclosure and land expropriation process. 


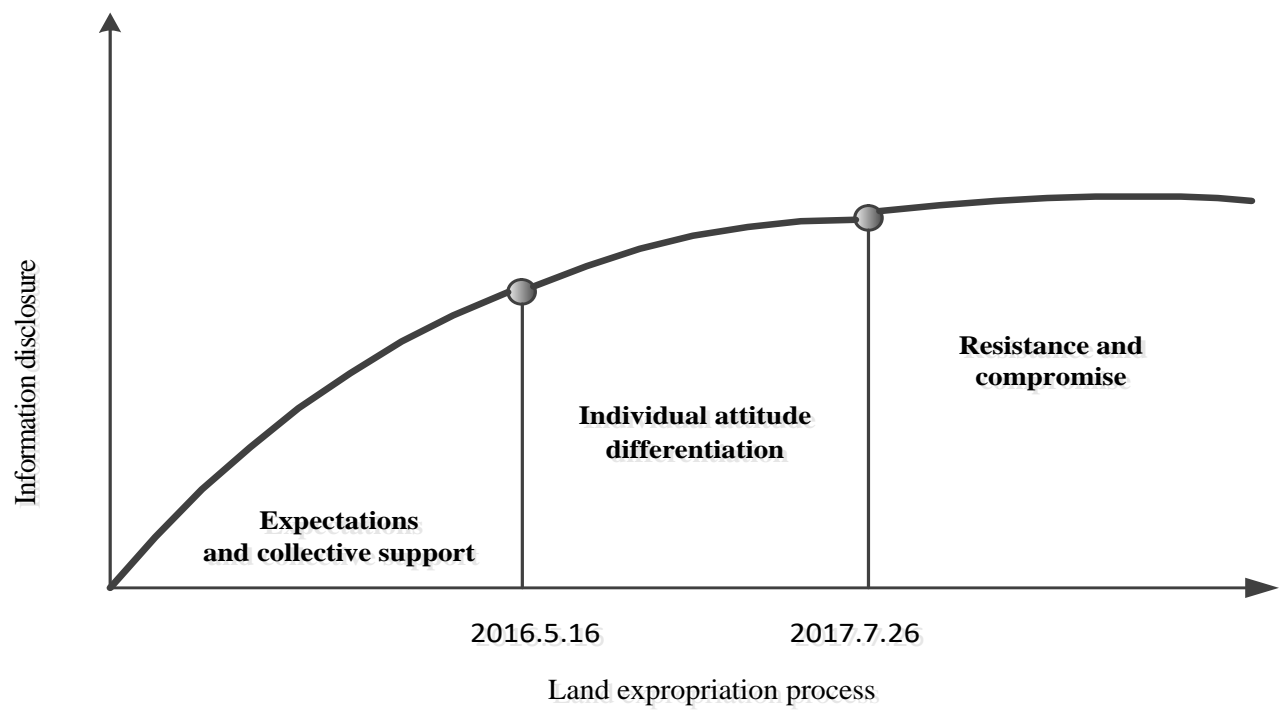

Figure 4. Villagers' attitudinal changes regarding land expropriation in the tourism development stage

\section{Implications}

This study offers new insights into residents' attitudes towards tourism, particularly rural tourism, in the pre-development stage (Nunkoo \& Ramkissoon, 2011). Residents' enthusiastic participation is crucial for the sustainable development of rural tourism (Ap, 1992; Davis \& Morais, 2004; Ko \& Stewart, 2002; McGehee \& Andereck, 2004; Teye, Sönmez, \& Sirakaya, 2002). The results of this longitudinal study can be used to evaluate residents' attitudinal changes towards land expropriation for tourism development. Thus, this study has the following specific implications.

\subsection{Theoretical implications}

This study explored land expropriation in the pre-tourism development stage in a nontourism area. By applying the longitudinal approach, this study provides rich theoretical insights. First, this research focuses on the residents' attitudes in the pre-tourism stage, which complements studies on tourism development. The classical research model does not include a pre-development stage and centres on tourism developments in later stages. However, all future tourist destinations pass through a pre-tourism stage, which suggests the need for more research (Hernandez, Cohen, \& Garcia, 1996; Hunt \& Stronza, 2014; Mason \& Cheyne, 2000; Sharply, 2014). This pre-tourism stage occurs just prior to a non-tourist destination becoming a tourist destination and reflects a time when communities have not yet directly experienced tourism and cannot accurately predict its impact. Residents can therefore be expected to have attitudinal responses to the initial changes brought by tourism. The findings of this study contribute to the literature on residents' attitudinal change by extending the research timeline backwards to the pre-development stage.

Second, this research considers the time factor in its explanation of residents' attitudinal change. Despite the potential for residents' attitudes to change over time, few studies have adopted a longitudinal approach (Lee \& Back, 2006). Longitudinal data offer greater insight than other kinds of data into attitudinal change. As shown in this study, residents' attitudinal changes in the pre-tourism stage were heterogeneous and dynamic. Both Doxey's Irridex model (1975) and Butler's lifecycle theory (1980) granted a certain degree of homogeneity to a community's attitudes towards tourism. However, more recent studies have shown 
considerable heterogeneity in such attitudes (Ap \& Crompton, 1993; Brougham \& Butler, 1981; Mason \& Cheyne, 2000). In the context of tourism development, changes in residents' individual attributes and in external conditions, such as those related to information, can lead to attitudinal change. Moreover, through in-depth interviews and non-participant observation, this paper identifies the specific mechanisms behind residents' attitudinal changes with the aim of understanding the root cause of such change, especially in less developed regions. Tourism, with its multiple stimulus effects, has become important in the economic development of many underdeveloped regions (Garrod, Wornell, \& Youell, 2006; Latkova \& Vogt, 2012).

Third, this study is a pioneer in adapting the persuasion situation model from the general social psychology field to resident studies in tourism. By specifying residents' attitudes in the 'external stimuli-targets-intervening processes-outcomes' flow, the study discovered nuanced attitudinal differences in each of the three stages in the land expropriation process and why and how the attitudes changed. For example, in this context, rural residents' overall education level and information accessibility level (Keogh, 1990) are low in general. Suddenly facing a tourism development project, inexperienced residents built up their attitudes towards the development based heavily on the reference groups' social influence, the power and force from authority and the tangible benefits that could be derived from the process. Applying the persuasion situation model also enabled the study to reveal the residents' struggles between losses and gains, their emotional attachment to the place and the compromises that some of them were willing to make. This mechanism is not unique to the residents' attitudinal changes; it is also applicable to the attitudinal changes of other stakeholders involved in the tourism development process. This study thus serves as a cornerstone for and offers essential insights into future attitude studies.

\subsection{Practical implications}

Consistent with this study's theoretical implications, this study's results also provide implications for managers and investors in the development of destination tourism.

The results improve understanding of differences in residents' demands and can thus be used to reduce social conflict. One driver of residents' attitudinal change is the prominence of their various demands in different phases of tourism development. According to SET (Ap, 1992), if residents perceive that the benefits of tourism development outweigh the costs, they become inclined to support the development. Social exchange should ideally rest on the principle of justice. If an exchange is unfair, the disadvantaged party may feel exploited, resulting in tension, dissatisfaction and conflict (Ap, 1992; Lee \& Back, 2003; Mathieson \& Wall, 1982). Residents should be at the centre of destination tourism development (Nunkoo \& Ramkissoon, 2011), as the success of such development largely hinges on their attitudes regarding the impact of tourism and can be viewed as important planning and policy considerations (e.g., Ap, 1992; Lankford \& Howard, 1994; Nunkoo \& So, 2016; Ribeiro et al., 2017; Sharpley, 2014). Local governments and developers should therefore consider residents' interests, enhance community participation (Wang et al., 2010), reduce social conflict and promote the sustainable development of local tourism.

The government should also formulate a fair and sound tourism development policy. Information asymmetry is a manifestation of power. Owing to China's unique land system, the government is responsible for making all of the rules on land expropriation. This power affects the interactions between stakeholders as they influence or attempt to influence the formulation and implementation of tourism policy (Hall, 1994). It also affects competition and resource distribution (Bramwell, 2006). The local government has been recognised as the most important authority in establishing tourism development policies (Pearce, 1989), and conflicts of interest frequently arise over how land is to be developed (Madrigal, 1995). In the case of Wudaoliang, the rights of residents were neglected, and the nature of the residents' external and own attributes led to their minimal participation. Clearly, local residents are often intentionally 
or unintentionally excluded from decision-making processes. They have few opportunities to exchange resources with government officials or developers on an equal basis, and the lack of those opportunities can lead to social conflict and even violence. Therefore, the government should establish standards of transparency and fairness for the tourism development process.

\section{Conclusion and limitations}

Residents' attitudes at an early stage are essential to the overall success of tourism development. Taking the land expropriation process in the pre-tourism development stage as the context, this research focused on the attitudinal changes of residents in the pre-tourism development stage. The study conducted non-participant observation and 180 interviews with a longitudinal approach. Three stages in the land expropriation process were identified, and the residents' attitudinal changes in each stage were delineated.

The results indicated that the attitudes of Wudaoliang's residents towards land expropriation for tourism development evolved dynamically over time. By adopting the model of persuasion situation, the study interpreted the residents' attitudinal changes by following the 'external stimuli-targets-intervening processes-outcomes' mechanism. As a result, residents' attitudes can be understood in terms of moving from expectations and collective support to individual differentiation and finally to resistance and compromise. The study not only discovered nuanced attitudinal differences in each of the three stages in the land expropriation process but also identified why and how the attitude changed. This mechanism is also applicable to the attitudinal changes of other stakeholders involved in the tourism development process. This study thus serves as a cornerstone for and offers essential insights into future attitude studies.

This study also provides implications for the government and investors in developing a destination in a socially sustainable way. The study emphasizes that residents should be treated as an important stakeholder in development rather than one to be exploited. Actions should be taken to reduce social conflicts in the development process. Clear land expropriation agreements should be provided with full details. All of the criteria, terms and conditions should be provided to the residents with necessary legal assistance. Local governments and developers should consider residents' interests, enhance community participation, reduce social conflict and promote the sustainable development of local tourism.

The research context of this paper is limited to the changes in residents' attitudes towards land expropriation for tourism development. The general attitude towards land expropriation is not discussed in this study, which is one of the limitations of this paper. Future research could explore the general attitude towards land expropriation and compare the differences accordingly. It is also noted that in the initial stage of tourism development, local community groups often have limited access to outside resources, limited bargaining power in tourism development and thus limited ability to fairly share the benefits of tourism development (Nunkoo \& Robin, 2015). Whereas the government and other stakeholders have direct and powerful influences on tourism development discourse, public interests tend to be marginalised (Dredge \& Jamal, 2013). Land expropriation for tourism development involves three key subjects in China: the local government, developers and residents. This paper starts from the perspective of residents and focuses on their attitude changes. The dynamic relationship between these three parties is also important to study in the future. Last, because of the implementation of socialist public ownership in general and the 'village collective' ownership of rural land in particular, land expropriation in China for rural tourism development is a unique phenomenon that is attracting increasing attention from academia and the industry. These conditions influence the dynamics of competing interests between residents, the government and business developers. Other regions may be subject to different procedures for land expropriation, and research in other contexts is necessary. 


\section{References}

Akis, S., Peristianis, N., \& Warner, J. (1996). Residents' attitudes to tourism development: The case of Cyprus. Tourism Management, 17(7), 481-494.

Allen, L. R., Hafer, H. R., Long, P. T., \& Perdue, R. R. (1993). Rural residents' attitudes toward recreation and tourism development. Journal of Travel Research, 31(4), 27-33.

Andereck, K. L., Valentine, K. M., Knopf, R. C., \& Vogt, C. A. (2005). Residents' perceptions of community tourism impacts. Annals of Tourism Research, 32(4), 1056-1076.

Andriotis, K., \& Vaughan, R.D. (2003). Urban residents' attitudes toward tourism development: The case of Crete. Journal of Travel Research, 42(2), 172-185.

Ap, J. (1992). Residents' perception on tourism impacts. Annals of Tourism Research, 19(4), 665-690.

Ap, J., \& Crompton, J. L. (1993). Residents' strategies for responding to tourism impacts. Journal of Travel Research, 32(1), 47-50.

Belisle, F. J., \& Hoy. D. R. (1980). The perceived impact of tourism by residents: A case study in Santa Marta, Colombia. Annals of Tourism Research, 7(1), 83-101.

Bramwell, B. (2006). Actors, power, and discourses of growth limits. Annals of Tourism Research, 33(4), 957-978.

Brougham, J. E., \& Butler, R. W. (1981). A segmentation analysis of resident attitudes to the social impact of tourism. Annals of Tourism Research, 8(4), 569-590.

Brunt, P., \& Courtney, P. (1999). Host perceptions of sociocultural impacts. Annals of Tourism Research, 26(3), 493-515.

Butler, R. W. (1980). The concept of the area cycle evolution: Implications for management of resources. Canadian Geographer, 24(1), 5-12.

Cai, M. (2016). Land for welfare in China. Land Use Policy, 55, 1-12.

Cai, M. \& Sun, X. (2018). Institutional bindingness, power structure, and land expropriation in China. World Development, 109, 172-186.

Cao, Y., \& Zhang, X. L. (2018). Are they satisfied with land taking? Aspects on procedural fairness, monetary compensation and behavioural simulation in China's land expropriation story. Land Use Policy, 74, 166-178.

Carmichael, B., Peppard, D., \& Boudreau, F. (1996). Mega-resort on my doorstep: Local resident attitudes toward Foxwood Casino and casino gambling on nearby Indian reservation land. Journal of Travel Research, 34(3), 9-16.

Churchill, G. (1991). Marketing research: Methodological foundations. Chicago: The Dryden Press.

Clarke, V., \& Braum, V. (2017). Thematic analysis. The Journal of Positive Psychology, 12(3), 297-298.

Clementi, N. C., Revelli, J. A., \& Sibona, G. J. (2015). Internal-external stimulus competition in a system of interacting moving particles: Persuasion versus propaganda. Physical Review, 92(1), 012816.

Creswell, J.W. (2014). A concise introduction to mixed methods research. Los Angeles: Sage Publications.

Davis, D., Allen, J., \& Cosenza, R. M. (1988). Segmenting local residents by their attitudes, interests, and opinions toward tourism. Journal of Travel Research, 27(2), 2-8.

Davis, J. S., \& Morais, D. B. (2004). Factions and enclaves: Small towns and socially 
unsustainable tourism development. Journal of Travel Research, 43(1), 3-10.

Doxey, G. (1975). A causation theory of visitor-resident irritants; methodology and research inferences. In proceedings of the Travel Research Association Sixth Annual Conference, Salt Lake City.

Dredge, D., \& Jamal, T. (2013). Mobilities on the gold coast, Australia: Implications for destination governance and sustainable tourism. Journal of Sustainable Tourism, 21(4), 557-579.

Dyer, P., Gursoy, D., Sharma, B., \& Carter, J. (2007). Structural modelling of resident perceptions of tourism and associated development on the sunshine coast, Australia. Tourism Management, 28(2), 409-422.

Faulkner, B., \& Russell, R. (1997). Chaos and complexity in tourism: In search of a new perspective. Pacific Tourism Review, 1(2), 93-102.

Freedman, J. L. (1985). Social Psychology (5th ed). Englewood Cliffs, NJ: Prentice-Hall.

Friestad, M., \& Wright, P. (1994). The persuasion knowledge model: How people cope with persuasion attempts. Journal of Consumer Research, 21(1), 1-31.

Garrod, B., Wornell, R., \& Youell, R. (2006). Re-conceptualising rural resources as countryside capital: The case of rural tourism. Journal of Rural Studies, 22(1), 117-128.

Getz, D. (1994). Residents' attitudes towards tourism. A longitudinal study in Spey Valley, Scotland. Tourism Management, 15(4), 247-258.

Gunce, E. (2003). Tourism and local attitudes in Girne, Northern Cyprus. Cities, 20(3), 181195.

Guo, L., \& Gao, G. (2014). Research on the landless intention of land-lost peasants in povertystricken areas based on logistic models: Taking Bijie prefecture of Guizhou province as the object for empirical research. Natural Resource Economics of China, 27(4), 68-72.

Guo, X. L. (2001). Land expropriation and rural conflicts in China. The China Quarterly, 166, 422-439.

Gursoy, D., \& Rutherford, D. G. (2004). Host attitudes toward tourism: An improved structural model. Annals of Tourism Research, 31(3), 495-516.

Gursoy, D., Jurowski, C., \& Uysal, M. (2002). Resident attitudes: A structural modelling approach. Annals of Tourism Research, 29(1), 79-105.

Hall, C.M. (1994). Tourism and politics: Policy, power and place. Chichester: Wiley.

Hernandez, S. A., Cohen, J., \& Garcia, H. L. (1996). Residents' attitudes towards an instant resort enclave. Annals of Tourism Research, 23(4), 755-779.

Ho, P. (2001). Who owns China's land? Policies, property rights and deliberate institutional ambiguity. The China Quarterly, 166, 394-421.

Horn, C., \& Simmons, D. (2002). Community adaptation to tourism: comparisons between Rotorua and Kaikoura, New Zealand. Tourism Management, 23(2), 133-143.

Hovland, C. I., \& Weiss, W. (1953). Transmission of information concerning concepts through positive and negative instances. Journal of Experimental Psychology, 45(3), 175.

Huh, C., \& Vogt, C. A. (2007). Changes in residents' attitudes toward tourism over time: A cohort analytical approach. Journal of Travel Research, 46(4), 446-455.

Hunt, C., \& Stronza, A. (2014). Stage-based tourism models and resident attitudes towards tourism in an emerging destination in the developing world. Journal of Sustainable Tourism, 22(2), 279-298. 
Ingram, C., Caruana, R., \& Mccabe, S. (2017). Participative inquiry for tourist experience. Annals of Tourism Research, 65, 13-24.

Ji, Z. J., Jiang, Y. Y., \& Xie, T. (2017). The perceptions and attitudes of residents towards the impacts of tourism. Resources Science, 39(3), 396-407.

Johnson, J. D., Snepenger, D. J., \& Akis, S. (1994). Residents' perceptions of tourism development. Annals of Tourism Research, 21(3), 629-642.

Jones, R. A., Linder, D. E., Kiesler, C. A., Zanna, M., \& Brehm, J. W. (1968). Internal states or external stimuli: Observers' attitude judgments and the dissonance-theory-self-persuasion controversy. Journal of Experimental Social Psychology, 4(3), 247-269.

Keogh, B. (1990). Public participation in community tourism planning. Annals of Tourism Research, 17(3), 449-465.

Khantimirov, D., \& Karande, K. (2018). Complaint as a persuasion attempt: Front line employees' perceptions of complaint legitimacy. Journal of Retailing and Consumer Services, 43, 68-76.

King, B., Pizam, A., \& Milman, A. (1993). Social impacts of tourism: Host perceptions. Annals of Tourism Research, 20(4), 650-665.

Ko, D. W., \& Stewart, W. P. (2002). A structural equation model of residents' attitudes for tourism development. Tourism Management, 23(5), 521-530.

Lankford, S. V., \& Howard, D. R. (1994). Developing a tourism impact attitude scale. Annals of Tourism Research, 21(1), 121-139.

Latkova, P., \& Vogt, C. A. (2012). Residents' attitudes toward existing and future tourism development in rural communities. Journal of Travel Research, 51(1), 50-67.

Lawson, R., Williams, J., Young, T., \& Cossens, J. (1998). A comparison of residents' attitudes towards tourism in 10 New Zealand destinations. Tourism Management, 19(3), 247-256.

Lee, C. K., \& Back, K. J. (2003). Pre- and post-casino impact of residents' perception. Annals of Tourism Research, 30(4), 868-885.

Lee, C. K., \& Back, K. J. (2006). Examining structural relationships among perceived impact, benefit, and support for casino development based on 4 year longitudinal data. Tourism Management, 27(3), 466-480.

Lepp, A. (2004). Tourism in a rural Ugandan village: Impacts, local meaning and implications for development. Doctoral dissertation: University of Florida.

Lepp, A. (2007). Residents' attitudes towards tourism in Bigodi village, Uganda. Tourism Management, 28(3), 876-885.

Lin, Q., Tan, S., Zhang, L., Wang, S., Wei, C., \& Li, Y. (2018). Conflicts of land expropriation in China during 2006-2016: An overview and its spatio-temporal characteristics. Land Use Policy, 76, 246-251.

Lindberg, K., \& Johnson, R. L. (1997). Modelling resident attitudes toward tourism. Annals of Tourism Research, 24(2), 402-424.

Liu, J. C., \& Var, T. (1986). Resident attitudes toward tourism impacts in Hawaii. Annals of Tourism Research, 13(2), 193-214.

Liu, J. C., Sheldon, P. J., \& Var, T. (1987). Resident perception of the environmental impacts of tourism. Annals of Tourism Research, 14(1), 17-37.

Ma, B. (2017). Analysis and convergence of rural tourism land problem. Tourism Tribune, $32(8), 4-6$. 
Madrigal, R. (1993). A tale of tourism in two cities. Annals of Tourism Research, 20(2), 336353.

Madrigal, R. (1995). Residents' perceptions and the role of government. Annals of Tourism Research, 22(1), 0-102.

Mason, P., \& Cheyne, J. (2000). Residents' attitudes to proposed tourism development. Annals of Tourism Research, 27(2), 391-411.

Mathieson, A., \& Wall, G. (1982). Tourism: Economic, physical, and social impacts. Geographical Review, 73(4), 466.

Mathur, S. (2013). Use of land pooling and reconstitution for urban development: Experiences from Gujarat, India. Habitat International, 38, 199-206.

McCool, S. F., \& Martin, S. R. (1994). Community attachment and attitudes toward tourism development. Journal of Travel Research, 32(3), 29-34.

McGehee, \& Andereck, N. G. (2004). Factors predicting rural residents' support of tourism. Journal of Travel Research, 43(2), 131-140.

Nicholas, L. N., Thapa, B., \& Yong, J. K. (2009). Residents' perspectives of a world heritage site: The Pitons Management Area, St. Lucia. Annals of Tourism Research, 36(3), 390412.

Nunkoo, R., \& Gursoy, D. (2012). Residents' support for tourism: An identity perspective. Annals of Tourism Research, 39(1), 243-268.

Nunkoo, R., \& Ramkissoon, H. (2011). Developing a community support model for tourism. Annals of Tourism Research, 38(3), 964-988.

Nunkoo, R., \& Ramkissoon, H. (2012). Power, trust, social exchange and community support. Annals of Tourism Research, 39(2), 997-1023.

Nunkoo, R., \& Robin. (2015). Tourism development and trust in local government. Tourism Management, 46, 623-634.

Nunkoo, R., Smith, S. L. J., \& Ramkissoon, H. (2013). Residents' attitudes to tourism: A longitudinal study of 140 articles from 1984 to 2010. Journal of Sustainable Tourism, 21(1), 5-25.

Nunkoo, R., \& So, K. K. F. (2016). Residents' support for tourism testing alternative structural models. Journal of Travel Research, 55(7), 847-861.

Pearce, P. L. (1989). Tourist development (2nd ed.). London: Longman.

Petty, R. E. (2018). Attitudes and persuasion: Classic and contemporary approaches. New York: Routledge.

Petty, R. E., \& Cacioppo, J. T. (1986). The elaboration likelihood model of persuasion. In Communication and persuasion (pp. 1-24). Springer, New York, NY.

Pizam, A., \& Poleka, J. (1985). The perceived impacts of casino gambling on a community. Annals of Tourism Research, 12(2), 147-165.

Ribeiro, M. A., Pinto, P., Silva, J. A., et al. (2017). Residents' attitudes and the adoption of protourism behaviours: The case of developing island countries. Tourism Management, 61, 523-537.

Ryan, C., \& Montgomery, D. (1994). The attitudes of Bakewell residents to tourism and issues in community responsive tourism. Tourism Management, 15(5), 358-369.

Sargeson, S. (2016). Grounds for self-government? Changes in land ownership and democratic participation in Chinese communities. The Journal of Peasant Studies, 45(2), 321-346. 
Shang, C. R. (1998). Comparison of international practices of land expropriation and protection of land resource in China. Problems in Rural Economy, 5, 26-30.

Sharpley, R. (2014). Host perceptions of tourism: A review of the research. Tourism Management, 42(2), 37-49.

Sheldon, P. J., \& Var, T. (1984). Resident attitudes to tourism in North Wales. Tourism Management, 5(1), 40-47.

Sherif, M., \& Hovland, C. I. (1961). Social judgment: Assimilation and contrast effects in communication and attitude change. Oxford, England: Yale University Press.

Smith, S. (2010). Practical tourism research. Wallingford: CABI.

Sofield, T. H. B. (2003). Empowerment for sustainable tourism development. Oxford: Emerald Group Publishing Limited.

Teye, V., Sönmez, S. F., \& Sirakaya, E. (2002). Residents' attitudes toward tourism development. Annals of Tourism Research, 29(3), 668-688.

Tomljenovic, R., \& Faulkner, B. (2000). Tourism and older residents in a sunbelt resort. Annals of Tourism Research, 27(1), 93-114.

Tosun, C. (2002). Host perceptions of impacts: A comparative tourism study. Annals of Tourism Research, 29(1), 231-253.

Um, S., \& Crompton, J. L. (1987). Measuring residents' attachment levels in a host community. Journal of Travel Research, 26(1), 27-29.

Upchurch, R. S., \& Teivane, U. (2000). Resident perceptions of tourism development in Riga, Latvia. Tourism Management, 21(5), 499-507.

Wang, Y., Wall, G. (2007). Administrative arrangements and displacement compensation in top-down tourism planning: A case from Hainan Province, China. Tourism Management, $28,70-82$.

Wang, H., Yang, Z. P., Chen, L., Yang, J. J., \& Li, R. (2010). Minority community participation in tourism: A case of Kanas Tuva villages in Xinjiang, China. Tourism Management, 31(6), 759-764.

Weaver, D. B., \& Lawton, L. J. (2001). Resident perceptions in the urban-rural fringe. Annals of Tourism Research, 28(2), 439-458.

Yang, J., Ryan, C., \& Zhang, L. (2013). Social conflict in communities impacted by tourism. Tourism Management, 35(2), 82-93.

Yoon, Y., Gursoy, D., \& Chen, J. S. (2001). Validating a tourism development theory with structural equation modelling. Tourism Management, 22(4), 363-372.

Zamani-Farahani, H., \& Ghazali Musa. (2012). The relationship between islamic religiosity and residents' perceptions of socio-cultural impacts of tourism in Iran: Case studies of Sare'in and Masooleh. Tourism Management, 33(4), 802-814. 